\title{
PENINGKATAN KEMAMPUAN MENULIS CERPEN MELALUI PENDEKATAN KONTEKSTUAL PADA SISWA KELAS IX SMP UNISMUH MAKASSAR
}

\author{
Syekh Adiwijaya ${ }^{1}$ Irmawati $P^{2}$ \\ Fakultas Keguruan dan Ilmu Pendidikan, Universitas muhammadiyah Makassar \\ adiwijaya@gmail.com \\ Fakultas Keguruan dan Ilmu Pendidikan, Universitas muhammadiyah Makassar \\ irmawati@gmail.com
}

\begin{abstract}
The research was a classroom action research aimed at improving the quality of students learning Indonesian Makassar Unismuh junior class IXA through contextual approach. This study consisted of two cycles of the first cycle for 4 meetings and the second cycle for 4 meetings. The subjects were students of class IXA Makassar Junior Unismuh the number of 30 students in the first semester of the 2015/2016 school year on the subject of short stories. Collecting data through the test results of this research study, observation sheet activities of students and teachers as well as student questionnaire responses. Data were analyzed by descriptive quantitative and qualitative. Based on the analysis, the results of studying Indonesian students has increased, which includes the average score Indonesian learning outcomes of students in the first cycle was 75.5 with a standard deviation of 9.87. In the second cycle the average score Indonesian student learning outcomes is 85.2 with a standard deviation of 12.36. The percentage of students who achieve mastery minimum is 23 or $76.66 \%$ in the first cycle and 27 or $90 \%$ in the second cycle. While data on the observation of activity of students and teachers were analyzed qualitatively also increased for applied learning with contextual approach in class IXA Unismuh SMP. In addition, the students' response to the contextual approach was generally positive with the average number of 95.18. So in general it can be concluded that the quality of learning Indonesian students has increased.
\end{abstract}

Keywords: Quality of Learning, Contextual Approach.

\begin{abstract}
Abstrak
Jenis penelitian ini adalah Penelitian Tindakan Kelas (classroom action research) yang bertujuan untuk meningkatkan kualitas pembelajaran bahasa Indonesia siswa kelas $\mathrm{IX}_{\mathrm{A}} \mathrm{SMP}$ Unismuh Makassar melalui pendekatan kontekstual. Penelitian ini terdiri dari dua siklus yaitu siklus I selama 4 kali pertemuan dan siklus II selama 4 kali pertemuan. Subjek penelitian ini adalah siswa kelas IX $\mathrm{X}_{\mathrm{A}} \mathrm{SMP}$ Unismuh Makassar dengan jumlah siswa 30 pada semester ganjil tahun pelajaran 2015/2016 dengan pokok bahasan cerita pendek. Pengambilan data penelitian ini melalui tes hasil belajar, lembar observasi aktivitas siswa dan guru serta angket respon siswa. Data hasil penelitian dianalisis secara deskriptif kuantitatif dan kualitatif. Berdasarkan analisis, hasil belajar bahasa Indonesia siswa mengalami peningkatan, yang meliputi skor rata-rata hasil belajar bahasa Indonesia siswa pada siklus I adalah 75,5 dengan standar deviasi 9,87. Pada siklus II skor rata-rata hasil belajar bahasa Indonesia siswa adalah 85,2 dengan standar deviasi 12,36. Persentase siswa yang mencapai ketuntasan minimal adalah 23 atau 76,66 \% pada siklus I dan 27 atau 90\% pada siklus II. Sedangkan data hasil observasi aktivitas siswa dan guru yang dianalisis secara kualitatif juga mengalami peningkatan selama diterapkan pembelajaran dengan pendekatan kontekstual pada siswa kelas $\mathrm{IX}_{\mathrm{A}}$ SMP Unismuh. Selain itu, respon siswa terhadap pendekatan kontekstual secara umum positif dengan jumlah rata-rata sebesar 95,18. Sehingga secara umum dapat disimpulkan bahwa kualitas pembelajaran bahasa indonesia siswa mengalami peningkatan.
\end{abstract}

Kata Kunci : Kualitas Pembelajaran, Pendekatan Kontekstual.

\section{PENDAhuluan}


Pengajaran bahasa Indonesia di sekolah tidaklah lepas dari mengajaran sastra yang tidak terlepas dari pengajaran cerpen. Pengajaran sastra di sekolah harus juga dipahami oleh siswa karena dalam pengajaran bahasa Indonesia tidak hanya semata-mata mengajarkan mengenai bahasa tetapi mereka juga harus paham dengan pembelajaran sastra misalkan dalam penulisan cerpen.

Untuk mencapai pengajaran tersebut, tentunya banyaklah hal yang bisa dilakukan. Sebagai guru bahasa Indonesia harus lebih memperhatikan cara mengajarnya, tidak sekedar mengajarkan materi tersebut tetapi melihat kondisi siswa apakah cara yang digunakan sudah membuat siswa paham dengan materi yang diajarkan. Pada umumnya guru hanya sekedar mengajar, tidak memperhatikan apakah cara mengajarnya sudah memenuhi tujuan pembelajaran yang akan dicapai. Guru yang seperti ini tidak memperhatikan keadaan siswanya dan itu bisa menimbulkan adanya rasa bosan dengan pelajaran tersebut atau akan berdampak pada mental siswa dengan kesiapan menerima pelajaran selanjutnya.

Pengajaran sastra khususnya cerpen biasanya tidak terlalu dipahami oleh siswa, untuk memberikan pemahaman siswa dalam penulisan cerpen guru bahasa Indonesia harusnya lebih memperkenalkan cerpen kepada mereka. Guru lebih membimbing siswa untuk memahami cerpen, guru bahasa Indonesia harus lebih banyak memperkenalkan cerpen kepada siswa. Guru dapat membantu memahami cerpen, membantu mengenali cerpen dengan nilai keindahannya sebagai sastra sehingga menimbulkan rasa kecintaannya dengan cerpen.

Salah satu pendekatan yang bisa dilakukan dalam pengajarn cerpen yaitu pendekatan kontekstual, dalam pendekatan ini yaitu pendekatan siswa diajarkan untuk lebih aktif dalam belajar sehingga tidak bergantung pada informasi yang diberikan oleh guru, selain itu siswa akan lebih mengerti tentang pelajaran yang akan dibahas karena mereka dapat menghubungkannya dengan situasi kehidupan nyata dan dapat diterapkan dalam kehidupan sehari-hari.

Studi pendahuluan yang dilakukan di kelas IX SMP Unismuh Makassar, melalui observasi yang dilakukan peneliti tentang pembelajaran Bahasa Indonesia di kelas IX, diketahui beberapa permasalahan yang dihadapi pada pembelajaran di kelas tersebut, di antaranya: (1) guru masih menggunakan model pembelajaran langsung (ceramah), (2) pembelajaran diawali dengan menyuruh siswa membuka buku paket, kemudian menyuruh siswa membaca dan menjawab pertanyaan yang telah dibacanya, (3) nilai rata-rata hasil belajar siswa pada mata pelajaran Bahasa Indonesia khususnya pada materi cerpen berada dalam kategori rendah yaitu 65, masih berada di bawah nilai KKM yang telah ditetapkan di sekolah tersebut yaitu 70 dari skor ideal.

Hal ini dapat dilihat pada buku daftar nilai harian dan hasil ulangan harian siswa pada kelas tersebut, nilai rata-rata siswa hanya mencapai 65 . Nilai rata-rata ini jika dibandingkan dengan kriteria ketuntasan minimum (KKM) yakni sebesar 70, maka dapat dikatakan bahwa nilai tersebut berada dibawah standar ketuntasan yang diharapkan. Hal ini menunjukkan kualitas pembelajaran bahasa Indonesia masih perlu untuk lebih ditingkatkan.

Oleh karena itu peneliti bermaksud menggunakan pembelajaran dengan pendekatan kontekstual, dimana dengan pendekatan kontekstual diharapkan hasil pembelajaran siswa dapat lebih bermakna bagi siswa. Pembelajaran kontekstual dapat memperkuat dimilikinya pengalaman belajar yang aplikatif bagi siswa, memberikan kesempatan kepada siswa untuk melakukan, mencoba, dan mengalami sendiri (learning to do), dan bahkan sebagai pendengar yang pasif terhadap informasi yang diberikan oleh guru.

Melalui pembelajaran kontekstual, dalam mengajar tidak hanya berbagi ilmu pengetahuan dari guru kepada siswa dengan menghafal sejumlah materi pengajaran, tetapi memfasilitasi siswa untuk mencari kemampuan untuk bisa hidup (life skill) dari 
apa yang dipelajarinya. Dengan demikian, pembelajaran akan lebih bermakna, sekolah lebih dekat dengan lingkungan masyarakat, dan siswa tidak mudah lupa dengan pelajaran walaupun dalam waktu yang cukup lama.

Variasi gaya bahasa atau style disebabkan pleh perbedaan gaya. Gaya adalah cara berbahasa seseorang dalam performanya secara terencana maupun tidak, baik secara lisan maupun tertulis. Variasi ini berwujud ragam bahasa (Kusumaningsih, dkk. 2013: 15).

Bahasa Indonesia yang digunakan saat ini berasal dari bahasa Melayu yang pada awalnya adalah salah satu bahasa daerah diantara berbagai bahasa daerah di kepulauan Indonesia. Bahasa melayu sebgai bahasa daerah dituturkan oleh suku melayu yang mendiami pesisir Timur pulau Sumatra, Semenanjung malaka, dan pesisir Barat Kalimantan (Rahim, dkk. 2013 :2).

Husein (dalam Rahim, dkk. 2013: 3) menyebutkan bahwa jauh sebelum Negara Republik Indonesia lahir, bahasa Melayu telah menjadi bahasa Melayu yang telah menjadi bahasa pergaulan (Lingua franca) di kepulauan nusantara, baik antara warga suatu suku atau etnik (norma intratnik). Mauapun sebagai bahasa pergaualan antara suku bangsa (norma supraetnik), bahkan bahasa Melayu telah menjadi bahasa perhubungan antar bangsa terutama untuk kawasan Asia Tenggara (norma supranasional).

Banyak pertanyaan yang sering muncul ketika selesai membaca sebuah cerita pendek atau cerpen. Sebagai pembaca, tentu sah untuk mempertanyakan pesan yang coba diampaikan penulis melalui cerita tersebut. Setiap karya fiksi tentu mengandung atau menawarkan tema, namun isi tema itu sendiri tak mudah ditunjukkan. Nurgiantoro, (dalam jathee, 2014: 1)

Menulis sebagai rangkaian kegiatan seseorang dalam mengungkapkan gagasan dan mengungkapkan melalui bahasa tulisan kepada pembaca, untuk dipamahami tepat seperti yang dimaksudkan oleh pengarang. Dalam tulisan tersebut terdapt makna yang akan disampaikan pengarang terhadap pembaca, melalui tulisan tersebut penulis bisa membuat cerita, menyusun sebuah buku dll.

Keterampilan menulis sangat penting bagi siswa. Penulis perlu memiliki banyak ide, ilmu pengetahuan, dan pengalaman hidup. Hal ini merupakan modal dasar yang harus dimiliki dalam kegiatan menulis. Disamping modal dasar itu, seorang penulis harus menguasai banyak perbendaharaan kata untuk menyampaikan ide-ide, pengetahuan, serta pengalaman yang dimilikinya.

\section{a. Pengertian Menulis}

Menulis adalah kegiatan menyampaikan sesuatu menggunakan bahasa melului tulisan, dengan maksud dan pertimbangan tertentu untuk mencapi sesuatu yang dikehendaki. Di dalam dunia pendidikan, menulis akan tetap berharga, sebab menulis membantu seseorang lebih mudah. Menulis suatu alat yang sangat ampuh dalam belajar dengan sendirinya memainkan peran yang sangat penting dalam dunia pendidikan (Kusumaningsih, 2013: $65)$.

Banyak pertanyaan yang sering muncul ketika selesai membaca sebuah cerita pendek atau cerpen. Sebagai pembaca, tentu sah untuk mempertanyakan pesan yang coba diampaikan penulis melalui cerita tersebut. Setiap karya fiksi tentu mengandung atau menawarkan tema, namun isi tema itu sendiri tak mudah ditunjukkan. Nurgiantoro, (dalam jathee, 2014: 1)

Menulis sebagai rangkaian kegiatan seseorang dalam mengungkapkan gagasan dan mengungkapkan melalui bahasa tulisan kepada pembaca, untuk dipamahami tepat seperti yang dimaksudkan oleh pengarang. Dalam tulisan tersebut terdapt makna yang akan disampaikan pengarang terhadap pembaca, melalui tulisan tersebut penulis bisa membuat cerita, menyusun sebuah buku dll.

Keterampilan menulis sangat penting bagi siswa. Penulis perlu memiliki banyak ide, ilmu pengrtahuan, dan pengalaman hidup. Hal ini merupakan modal dasar yang harus dimiliki dalam kegiatan 
menulis. Disamping modal dasar itu, seorang penulis harus menguasai banyak perbendaharaan kata untuk menyampaikan ide-ide, pengetahuan, serta pengalaman yang dimilikinya.

Nurgiantori (dalam Munira, 2007: 1) menjelaskan bahwa menulis merupakan suatu bentuk manifestasi kemanpuan atau keterampilan berbahasa paling akhir diakui pelajar setelah kemanpuan mendengarkan, berbicara dan membaca.

Caraka (dalam Munira, 2007: 2) mengemukakan bahwa menulis berarti menggunakan bahasa untuk menyatakan isi hati dan buah pikiran secara menarik bagi pembaca. Ide yang jelas dan tertentu, mesti ada sebelum mulai mengarang agar tidak membuang waktu dan bicara tampa tujuan.

Jadi dapat disimpulkan bahwa menulis merupakan suatu kegiatan untuk menuangkan gagasan, ide, inspirasi yang ada dalam pikiran melalui bahasa agar dapat dipahami oleh orang lain.

\section{b. Tujuan Menulis}

Tujuan utama menulis adalah sebagai alat komunikasi secara tidak langsung. Penulis dan pembaca dapat berkomunikasi melalui tulisan. Pada prinsipnya menulis menyampaikan pesan penulis kepada pembaca, sehingga pembaca memahami maksud yang dituangkan atau maksud yang disampaikan melalui tulisan tersebut.

Mengingat komunikasi tersebut dilakukan secara tidak langsung, tidak melalui tatap muka antara pembaca dan penulis maka isi tulisan dan lambing grafik yang dipergunakan harus benar-benar jelas. Isi tulisan dan lambang grafik tersebut harus dapat dipahami oleh penulis dan pembaca. Hal ini bertujuan agar tulisan tersebut dapat berfungsi sebagai mana yang dimaksud oleh penulis (Kusumaningsi, dkk. 2013: 67).

Tarigan (dalam Munira, 2007: 6) merangkum tujuan penulisan sebagai berikut:
1) Tujuan penugasan. Pada tujuan ini, sebenarnya penulis menulis karena ditugasi

2) Tujuan altruistik. Penulis bertujuan menyenagkan, menghindarkan kedukaan, ingin menolong para pembaca memahami, menghargai perasaan, ingin membuat hidup para pembaca lebih muda dan lebih menyenangkan.

3) Tujuan persuasif. Penulis bertujuan meyakinkan para pembaca akan kebenaran yang diutarakan.

4) Tujuan penegasan. Penulis bertujuan memberikan informasi atau keterangan/penerangan kepada pembaca.

5) Tujuan peryataan diri. Penulis bertujuan memperkenalkan atau menyatakan diri kepada pembaca melalui tulisannya, pembaca dapat memahami sangpenulis.

6) Tujuan kreatif. Penulis bertuajuan agar pera pembaca dapat memiliki nilai artistik atau nilai kesenian.

Penuja (dalam Kusumaningsih, 2013: 69) ada lima tujuh utama dalam menulis, yaitu :

1) Tujuan menghibur: penulis bermaksud menghibur kepada pembaca sehingga pembaca merasa senang dan memgurangi kesedihan dari pembacanya.

2) Tujuan menyakinkan dan berdaya bujuk: karangan atau tulisan bertujuan menyakinkan dan berdaya bujuk termuat dalam isi.

3) Tujuan penerangan: isi karangan memberikan keterangan (informasi tentang segala hal kepada pembaca dan bersifat inivatif).

4) Tujuan pernyataan diri: pernyataan diri ini bertujuan untuk memperkenalkan atau menyatakan diri.

5) Tujuan kreatif: tujuan kreatif ini berkaiatn erat dengan tujuan 
pernyataan diri mengarah pada pencapaian nilai-nilai artistik.

Berdasarkan uraian di atas dapat disimpulkam, tujuan menulis ialah untuk mengeluarkan gagasan atau ide yang ada dalam pikiran dan dituangkan dalam bahasa agar dimengerti orang lain.

\section{c. Pengertian Cerpen}

Cerpen adalah bentuk prosa baru yang menceritakan sebagian kecil kehidupan pelakunya yang terpenting dan paling menarik. Di dalam cerpen boleh ada konflik atau pertikaian, akan tetapi hal itu tidak menyebabkan perubahan nasib pelakunya. Seringkas atau sependek apapun dalam sebuah cerpen pasti ada cerita (Rahim, dkk. 2013: 172).

Cukup banyak batasan atau pengertian cerpen yang dikemukakan para pakar, meskipun sampai sekarang pengertian cerpen masih sering diperbincangkan dan diperdebatkan. Berdasarkan uraian di atas dapat disimpulkan bahwa cerpen adalah suatu cerita yang memiliki sebuah masalah yang berkaiatan dalam kehidupan sehari-hari dan memiliki cerita yang singkat.

\section{d. Unsur-unsur dalam Cerpen}

Unsur-unsur dalam cerpen terdiri atas unsur intrinsik dan unsur ekstrinsik yang membentuk cerita dalam karya fiksi. Unsur ekstrinsik adalah segala macam unsur yang berada di luar suatu karya sastra yang ikut mempengaruhi kehadiran karya sastra itu, misalnya faktor sosial, ekonomi, politik, dan budaya. Sedangkan, unsur intrinsik adalah unsur membentuk cerpen sebagai salah satu karya sastra seperti penokohan, latar, alur, tema, sudut pandang, dan gaya bahasa. Rincian penjelasannya sebagai berikut.

1) Unsur-unsur Intrinsik

a) Penokohan/perwatakan

Tokoh dan perwatakan mestinya merupakan suatu struktur pula. Ia memiliki fisik dan mental yang secara bersama-sama membentuk suatu totalitas prilaku yang bersangkutan. Tokoh cerita biasanya mengemban suatu perwatakan tertentu yang diberi bentuk dan isi oleh pengarang.

\section{b) Plot/alur}

Alur adalah struktur rangkaian kejadian dalam cerita yang disusun sebagai sebuah interrelasi fungsional yang sekaligus menandai urutan bagian-bagian dalam keseluruhan fiksi. Alur menyajikan deretan peristiwa-peristiwa kepada pembaca, tidak hanya temporal tetapi dalam hubungan secara kebetulan.

\section{c) Latar}

Latar merupakan penanda identitas permasalahan fiksi yang mulai secara samar diperlihatkan alur atau penokohan. Latar juga meliputi lingkungan tempat peristiwa terjadi termasuk di dalamnya tempat atau ruangan yang diamati. Biasanya muncul pada semua bagian atau penggalan cerita.

\section{d) Tema}

Tema adalah topik dalam pokok pembicaraan dalam tulisan atau karya fiksi. Jadi tema tidak lain merupakan suatu gagasan sentral dalam sebuah cerpen.

e) Sudut Pandang

Sudut pandang adalah posisi dan penempatan diri pengarang dalam ceritanya atau dari mana ia melihat peristiwa-peristiwa yang terdapat dalam cerita itu.

f) Gaya Bahasa

Gaya bahasa dalam karya naratif merupakan bentuk-bentuk ungkapan yang digunakan oleh pengarang untuk menyampaikan ceritanya.

g) Amanat

Amanat adalah unsur pendidikan, terutama pendidikan moral, yang ingin disampaikan oleh pengarang kepada pembaca lewat karya sastra yang ditulisnya. Unsur pendidikan ini tidak dituliskan secara langsung. Pembaca baru dapat mengetahui unsur pendidikannya setelah membaca seluruh karya sastra.

2) Unsur-unsur Ekstrinsik 
a). Latar belakang pengarang

Kehidupan pengarang dan kejiwaannya berpengaruh terhadap proses penciptaan karya sastra.

\section{b). Aspek-aspek sosial politik}

Situasi sosial politik seperti masalah ekonomi, budaya, dan pendidikan akan berpengaruh terhadap karya sastra.

\section{3) Acuan Teori Tindakan yang Dipilih}

\section{1) Contextual Teaching and Learning} (CTL) sebagai Suatu Pendekatan

Menurut Kubi (dalam Kusuma, 2010: 57) kata kontekstual (contextual) asal kata dari context yang berarti "hubungan, konteks, suasana dan keadaan (konteks)". Sehingga Contextual Teaching and Learning (CTL) dapat diartikan suatu pembelajaran yang berhubungan dengan suasana tertentu.

Menurut Johnson (2011: 57) Contextual Teaching and Learning (CTL) adalah sebuah sistem yang merangsang otak untuk menyusun pola-pola yang mewujudkan makna. CTL adalah suatu sistem yang cocok dengan otak karena menghasilkan makna dengan menghubungkan muatan akademis dengan konteks dari kehidupan sehari-hari siswa.

Pendekatan kontekstual mengakui bahwa belajar merupakan sesuatu yang kompleks dan multidimensi yang jauh melampaui berbagai metodologi yang hanya berorientasi kepada latihan/tanggapan (stimulus-respon). CTL menuntut siswa bekerja dalam kelompok dalam melaksanakan pekerjaan mereka. Berdasarkan teori pendekatan kontekstual, belajar hanya terjadi jika siswa memproses informasi atau pengetahuan baru sedemikian rupa sehingga dirasakan masuk akal dan sesuai dengan kerangka berfikir yang dimilikinya (ingatan, pengalaman, dan tanggapan).

Dalam kelas kontekstual, tugas guru adalah membantu siswa mencapai tujuannya. Maksudnya guru lebih banyak berurusan dengan strategi daripada memberi informasi. Tugas guru mengelola kelas sebagai sebuah tim yang bekerja sama untuk menemukan sesuatu yang baru bagi anggota kelas (siswa). Suatu pengetahuan dan keterampilan yang datang dari "menemukan sendiri" daripada kata "guru".

Adapun pendekatan kontekstual yang dimaksud adalah cara mengajar yang digunakan untuk membantu siswa membawa pembelajaran ke dalam konteks yang nyata dan berusaha agar melalui pembelajaran tersebut siswa belajar dengan mengalami dan dapat mengkonstruksi pengetahuannya, dan dalam bentuk pembelajaran yang menarik dan menyenangkan tanpa ada rasa tegang dan takut pada matematika.

2) Karakteristik contextual teaching and learning

Terdapat beberapa karakteristik dalam proses pembelajaran yang menggunakan pendekatan kontekstual, (Andira, 2012: 16 ) yakni:

1) Kerjasama antar peserta didik dan guru

2) Saling menunjang/membantu antar peserta didik dan guru

3) Menyenangkan, tidak membosankan

4) Belajar dengan bergairah

5) Pembelajaran terintegrasi

6) Menggunakan berbagai sumber

7) Cara belajar siswa aktif

8) Sharing bersama teman

9) Siswa kritis dan guru kreatif

Dalam pengajaran kontekstual memungkinkan terjadinya lima bentuk belajar yang penting, yaitu mengaitkan (relating), mengalami (experiencing), menerapkan (applying), bekerjasama (cooperating), dan mentransper (transferring).

Tabel 2.1 Menurut Jauhar (dalam Andira, 2012: 16) Perbedaan pendekatan kontekstual dengan pendekatan tradisional antara lain, sebagai berikut : 


\begin{tabular}{|c|c|c|}
\hline No & Pendekatan CTL & Pendekatan Tradisional \\
\hline 1 & $\begin{array}{l}\text { Siswa secara aktif terlibat dalam } \\
\text { proses pembelajaran. }\end{array}$ & $\begin{array}{l}\text { Siswa adalah penerima informasi } \\
\text { secara pasif. }\end{array}$ \\
\hline \multirow[t]{2}{*}{2} & Siswa belajar dari teman melalui kerja & \multirow[t]{2}{*}{ Siswa belajar secara individual. } \\
\hline & $\begin{array}{l}\text { kelompok, } \\
\text { mengoreksi. }\end{array}$ & \\
\hline 3 & $\begin{array}{l}\text { Pembelajaran dikaitkan dengan } \\
\text { kehidupan nyata dan atau masalah } \\
\text { yang disimulasikan. }\end{array}$ & $\begin{array}{l}\text { Pembelajaran sangat abstarak dan } \\
\text { teoritis. }\end{array}$ \\
\hline 4 & $\begin{array}{l}\text { Keterampilan dikembangkan atas } \\
\text { dasar pemahaman. }\end{array}$ & $\begin{array}{l}\text { Keterampilan dikembangkan atas } \\
\text { dasar latihan. }\end{array}$ \\
\hline 5 & $\begin{array}{l}\text { Hadiah untuk perilaku baik adalah } \\
\text { kepuasan diri. }\end{array}$ & $\begin{array}{l}\text { Hadiah untuk perilaku baik adalah } \\
\text { pujian atau nilai (angka) rapor. }\end{array}$ \\
\hline 6 & $\begin{array}{l}\text { Seseorang tidak melakukan yang } \\
\text { jelek karena dia sadar hal itu keliru } \\
\text { dan merugikan. }\end{array}$ & $\begin{array}{l}\text { Seseorang tidak melakukan yang } \\
\text { jelek karena dia takut hukuman. }\end{array}$ \\
\hline 7. & $\begin{array}{l}\text { Siswa diminta bertanggung jawab dan } \\
\text { mengembangkan pembelajaran } \\
\text { mereka masing-masing. }\end{array}$ & $\begin{array}{l}\text { Guru adalah penentu jalannya } \\
\text { proses pembelajaran. }\end{array}$ \\
\hline 8 & $\begin{array}{l}\text { Hasil pelajar diukur dengan berbagai } \\
\text { cara : proses bekerja, hasil karya } \\
\text { penampilan, rekaman, tes dll. }\end{array}$ & $\begin{array}{l}\text { Hasil belajar diukur hanya dengan } \\
\text { tes. }\end{array}$ \\
\hline 9 & $\begin{array}{l}\text { Pembelajaran terjadi diberbagai } \\
\text { tempat konteks dan setting. }\end{array}$ & $\begin{array}{l}\text { Pembelajaran hanya terjadi dalam } \\
\text { kelas. }\end{array}$ \\
\hline 10 & $\begin{array}{l}\text { Penyesalan adalah hukuman dari } \\
\text { perilaku jelek. }\end{array}$ & $\begin{array}{l}\text { Sanksi adalah hukuman dari } \\
\text { perilaku jelek. }\end{array}$ \\
\hline 11 & $\begin{array}{l}\text { Seseorang berperilaku baik karena dia } \\
\text { yakin itulah yang terbaik dan } \\
\text { bermanfaat. }\end{array}$ & $\begin{array}{l}\text { Seseorang berperilaku baik karena } \\
\text { dia terbiasa melakukan begitu, } \\
\text { kebiasaan itu dibangun dengan } \\
\text { hadiah yang menyenangkan. }\end{array}$ \\
\hline
\end{tabular}

\section{METODE}

Jenis penelitian ini merupakan penelitian tindakan kelas (Classroom Action Research), yang dibagi dalam dua siklus dengan empat tahapan, yaitu perencanaan, tindakan, observasi, dan refleksi. Tindakan yang diberikan adalah pembelajaran bahasa Indonesia dengan menerapkan pendekatan kontekstual untuk meningkatkan kualitas pembelajaran cerpen dengan pendekatan kontekstual.

Pada penelitian ini yaitu penelitian tindak berbasis kelas, rencana tindakan berupa intervensi kegiatan belajar mengajar di kelas dengan desain materi dan tugas perkelompok dalam bentuk LKS yang mengacu kepada pendekatan kontekstual. Untuk maksud tersebut tindakan akan dilakukan selama delapan pertemuan. Siklus I dilaksanakan 4 kali pertemuan dan dilaksanakan evaluasi pada pertemuan ke- 4, demikian pula siklus II terdiri dari 4 kali pertemuan dan pertemuan ke- 4 dilaksanakan evaluasi.

Pada penelitian ini yaitu penelitian tindak berbasis kelas, rencana tindakan berupa intervensi kegiatan belajar mengajar di kelas dengan desain materi dan tugas perkelompok dalam bentuk LKS yang mengacu kepada pendekatan kontekstual. Untuk maksud tersebut tindakan akan 
dilakukan selama delapan pertemuan. Siklus I dilaksanakan 4 kali pertemuan dan dilaksanakan evaluasi pada pertemuan ke-4, demikian pula siklus II terdiri dari 4 kali pertemuan dan pertemuan ke- 4 dilaksanakan evaluasi.

Teknik Analisis Data

Data yang dikumpulkan dianalisis secara kualitatif dan kuantitatif. Data hasil observasi dianalisis secara kualitatif sedangkan hasil belajar siswa dianalisis secara kuantitatif dengan menggunakan analisis deskriptif.

Tabel 1 Teknik Kategorisasi Standar Berdasarkan Ketetapan KementerianPendidikan Nasional

\begin{tabular}{cc}
\hline Skor & Kategori \\
\hline $0<\mathrm{x} \leq 54$ & Sangat rendah \\
\hline $54<\mathrm{x} \leq 64$ & Rendah \\
\hline $64<\mathrm{x} \leq 79$ & Sedang \\
\hline $79<\mathrm{x} \leq 89$ & Tinggi \\
\hline $89<\mathrm{x} \leq 100$ & Sangat tinggi
\end{tabular}

Sumber: Ernawati (dalam Suryani, 2015)

Ketuntasan belajar klasikal = $\frac{\text { jumlah siswa yang tuntas }}{\text { jumlah seluruh siswa }} \times 100 \%$

\section{HASIL PENELITIAN}

Hasil penelitian yang menunjukkan peningkatan kualitas pembelajaran bahasa Indonesia siswa kelas IX SMP Unismuh Makassar setelah diterapkan pembelajaran dengan pendekatan kontekstual. Data hasil penelitian ini adalah data yang diperoleh dari tes hasil belajar siswa setelah pelaksanaan tindakan siklus I dan siklus II serta data aktivitas siswa dan keterlaksanaan pembelajaran yang diperoleh dari hasil observasi. Hasil dan pembahasan yang diperoleh dari pelaksanaan penelitian ini dapat diuraikan sebagai berikut:

\section{a. Observasi dan Evaluasi}

1. Skor Analisis Data Kuantitatif Siklus I

Dari analisis deskriptif tentang skor hasil belajar bahasa Indonesia Siklus I dapat dilihat pada Tabel 1 berikut ini.

Tabel 1 Statistik Skor Hasil Belajar bahasa Indonesia Siswa Kelas IX ${ }_{A}$ SMP Unismuh Makassar pada Siklus I

\begin{tabular}{cc}
\hline Statistik & Nilai Statistik \\
\hline Subjek & 30 \\
\hline Skor Rata-rata & 75,5 \\
\hline Median & 74,5 \\
\hline Modus & 76 \\
\hline Standar Deviasi & 9,87 \\
\hline Variansi & 97,59 \\
\hline Skor Terendah & 58 \\
\hline Skor Tertinggi & 96 \\
\hline Rentang Skor & 38
\end{tabular}

Apabila skor hasil belajar bahasa Indonesia siswa dikelompokkan kedalam lima kategori, maka diperoleh distribusi frekuensi yang ditunjukkan pada Tabel 2 berikut ini.

Tabel .2 Distribusi Frekuensi dan

Persentase Skor Hasil Belajar bahasa Indonesia Siswa Kelas IX A $_{\mathrm{A}}$ SMP Unismuh Makassar pada Siklus I 


\begin{tabular}{|c|c|c|c|c|}
\hline No & Skor & Kategori & Frekuensi & Persentase (\%) \\
\hline 1. & $0 \leq x \leq 64$ & Sangat rendah & 5 & 16,66 \\
\hline 2. & $65 \leq x \leq 74$ & Rendah & 2 & 6,66 \\
\hline 3. & $75 \leq x \leq 79$ & Sedang & 11 & 36,66 \\
\hline 4. & $80 \leq x \leq 85$ & Tinggi & 7 & 23,33 \\
\hline 5. & $86 \leq x \leq 100$ & Sangat tinggi & 5 & 16,66 \\
\hline \multicolumn{3}{|c|}{ Jumlah } & 30 & 100 \\
\hline
\end{tabular}

Berdasarkan tabel 1 dan .2 bahwa hasil belajar bahasa Indonesia pada siswa

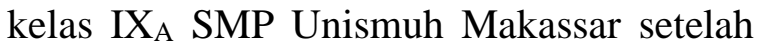
dilakukan tindakan pada siklus I berada dalam kategori rendah dengan skor rata-rata 75,5 dengan standar deviasi 9,87 dan variansi 97,59. Perolehan skor untuk siklus I adalah 96 untuk skor tertinggi dan 58 untuk skor terendah dari skor ideal yang mungkin dicapai yaitu 100. Kemudian, persentase ketuntasan belajar bahasa Indonesia siswa setelah tindakan pembelajaran pada siklus I dapat dilihat pada tabel 3 berikut ini:

Tabel 3 Deskriptif Ketuntasan Hasil Belajar Bahasa Indonesia Siswa Kelas IX A SMP Unismuh Makassar pada Siklus I

\begin{tabular}{cccc}
\hline Skor & Kategori & Frekuensi & Persentase (\%) \\
\hline $0 \leq x \leq 69$ & Tidak Tuntas & 7 & 23,33 \\
\hline $70 \leq x \leq 100$ & Tuntas & 23 & 76,66 \\
\hline & & & 100 \\
\hline
\end{tabular}

Dari tabel 3 menunjukkan bahwa persentase ketuntasan belajar siswa kelas $\mathrm{IX}_{\mathrm{A}}$ SMP Unismuh Makassar sebesar 76,66\% atau 23 dari 30 siswa termasuk dalam kategori tuntas dan $23,33 \%$ atau 7 dari 30 siswa termasuk kategori tidak tuntas. Ini berarti 7 orang siswa tersebut perlu perbaikan karena belum mencapai ketuntasan Minimal (KKM).

\section{a. Refleksi}

Pertemuan pertama pada Siklus I merupakan pembelajaran awal dan menggunakan pendekatan yang baru dikenal oleh siswa dibandingkan dengan pertemuanpertemuan sebelum diadakan penelitian.
Sehingga pertemuan ini merupakan tahap pengenalan dan penyesuaian terhadap pendekatan dan model yang diterapkan akibatnya siswa agak sedikit bingung. Selanjutnya pada pertemuan kedua dan ketiga mereka sedikit lebih paham karena diberikan perhatian yang lebih dibandingkan dengan pertemuan pertama. Hal ini menyebabkan tidak maksimalnya penelitian pada Siklus I itu terlihat dari hasil tes Siklus I masih banyak nilai siswa dibawa Kriteria Ketuntasan Minimal ( KKM).

\section{b. Keputusan}

Karena hasil siswa pada akhir Siklus I belum menunjukkan hasil yang optimal dan 
belum meratanya pemahaman siswa terhadap penerapan pembelajaran dengan pendekatan kontekstual maka dasar acuan ini dilanjutkan pelaksanaan tindakan pada Siklus II dengan mengupayakan perbaikan melalui penerapan pembelajaran dengan pendekatan kontekstual dengan:

1. lebih meningkatkan keaktifan siswa dengan cara memperbanyak latihan baik dalam kelas maupun dirumah, serta menekakan bahwa siswa aktif bertanya, memjawab pertanyaan lisan guru, dan mengerjakan soal akan memperoleh nilai tambah.

2. Lebih memperketat pengawasan kepada siswa yang sering melakukan kegiatan yang kurang positif di dalam kelas dan memberikan sanksi kepada siswa yang masih melakukan hal-hal yang kurang positif di dalam kelas, seperti mengerjakan.

3. Menekankan kepada semua kelompok untuk duduk bersama dengan anggota kelompoknya sebelum pelajaran dimulai.

4. Mengubah setting tempat duduk dan jarak bangku antar tiap kelompok agar kejadian-kejadian yang kurang positif dapat diminimalisir.

Berdasarkan tabel aktivitas siswa pada siklus I dapat dijabarkan sebagai berikut:

1) Pada siklus I masih ada siswa yang tidak hadir mengikuti pelajaran baik itu tidak hadir tanpa keterangan maupun yang sakit dan izin.

2) Perhatian siswa pada siklus I ini masih berjalan seperti biasa masih kurang antusias siswa dalam menyelesaikan tugas dan masih kurangnya kerja sama siswa dalam membantu temannya menyelesaikan LKS secara kelompok.

3) Pada siklus I keaktifan siswa dalam proses pembelajaran seperti menjawab pertanyaan, bertanya tentang materi yang sedang dibahas masih rendah.

4) Pada siklus I kepasifan siswa dalam proses pembelajaran masih tinggi, dalam hal ini mengajukan diri naik mengerjakan soal yang masih didominasi oleh siswa yang pintar dan itupun jika ditunjuk.

5) Pada siklus I masih banyak siswa yang melakukan kegiatan lain seperti ribut, ke WC, dan bermain dalam kelas.

\section{a. Observasi dan Evaluasi}

1. Hasil Analisis Data Kuantitatif Siklus II

Dari analisis analisis deskriptif tentang skor hasil belajar matematika pada Siklus II dapat dilihat pada pada tabel 4 berikut ini.

Tabel 4 Statistik Skor Hasil Belajar Bahasa Indonesia Siswa Kelas IX SMP Unismuh Makassa pada Siklus II

\begin{tabular}{cc}
\hline Statistik & Nilai Statistik \\
\hline Subjek & 30 \\
\hline Skor Rata-rata & 82,2 \\
\hline Median & 80 \\
\hline Modus & 100 \\
\hline Standar Deviasi & 12,36 \\
\hline Variansi & 152,80 \\
\hline Skor Terendah & 60 \\
\hline Skor Tertinggi & 100 \\
\hline Rentang Skor & 40 \\
\hline
\end{tabular}

Apabila skor hasil belajar bahasa Indonesia siswa dikelompokkan kedalam lima kategori, maka diperoleh distribusi 
frekuensi yang ditunjukkan pada Tabel 5 berikut ini.

Tabel 5 Distribusi Frekuensi dan

Persentase Skor Hasil Belajar
Bahasa Indonesia Siswa Kelas IX SMP Unismuh Makassar pada

Siklus II

\begin{tabular}{|c|c|c|c|c|}
\hline No & Skor & Kategori & Frekuensi & Persentase (\%) \\
\hline 1. & $0 \leq x \leq 64$ & Sangat rendah & 1 & 3,33 \\
\hline 2. & $65 \leq x \leq 74$ & Rendah & 0 & 0 \\
\hline 3. & $75 \leq x \leq 79$ & Sedang & 6 & 20 \\
\hline 4. & $80 \leq x \leq 85$ & Tinggi & 5 & 16,66 \\
\hline 5. & $86 \leq x \leq 100$ & Sangat tinggi & 16 & 53,33 \\
\hline \multicolumn{3}{|c|}{ Jumlah } & 30 & 100 \\
\hline
\end{tabular}

Berdasarkan tabel 4 dan 5 bahwa hasil belajar bahasa Indonesia pada siswa

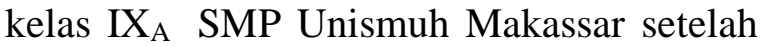
dilakukan tindakan pada siklus II berada dalam kategori tinggi dengan skor rata-rata 82,2 dengan standar deviasi 12,36 dan variansi 152,80.

Perolehan skor untuk siklus II adalah 100 untuk skor tertinggi dan 60 untuk skor terendah dari skor ideal yang mungkin dicapai yaitu 100. Kemudian, persentase ketuntasan belajar bahasa Indonesia siswa setelah tindakan pembelajaran pada siklus II dapat dilihat pada tabel 6 berikut ini:

Tabel 6 Deskriptif Ketuntasan Hasil Belajar Bahasa Indonesia kelas IX $\mathrm{A}_{\mathrm{A}}$ SMP Unismuh Makassar pada Siklus II

\begin{tabular}{cccc}
\hline Skor & Kategori & Frekuensi & Persentase (\%) \\
\hline $0 \leq x \leq 74$ & Tidak Tuntas & 3 & 10 \\
\hline $75 \leq x \leq 100$ & Tuntas & 27 & 90 \\
\hline & & & 100 \\
\hline
\end{tabular}

Dari tabel 6 menunjukkan bahwa persentase ketuntasan belajar siswa kelas IX A $_{\mathrm{A}}$ SMP Unismuh Makassar sebesar 90\% termasuk dalam kategori tuntas dan $10 \%$ termasuk dalam kategori tidak tuntas. Hal ini dapat memberikan gambaran bahwa pelaksanaan pembelajaran siswa bahasa Indonesia melalui pendekatan kontekstual pada siklus II mencapai ketuntasan klasikal yaitu $90 \%$ siswa mencapai atau lebih dari skor kriteria ketuntasan minimal (KKM).

Berdasarkan tabel 4.9 di atas, aktivitas siswa pada siklus II dapat dijabarkan sebagai berikut :

1) Pada siklus II tampak perubahan dengan ketidakhadiran siswa hampir tidak ada dibandinkan dengan siklus I 
2) Pada siklus II keaktifan siswa sudah meningkat dalam proses belajar mengajar seperti manjawab pertanyaan, sudah berani bertanya dan berebutan manaikkan tangan untuk menjawab pertanyaan dari guru.

3) Pada siklus II kepasifan siswa dalam proses pembelajaran sudah rendah, dalam hal ini siswa sudah berani menjawab pertanyaan serta mengerjakan soal di papan tulis tanpa ditunjuk.

4) Selama siklus II berlangsung. Perhatian siswa sudah meningkat dengan ditandai banyaknya siswa yang menyetor pekerjaan rumah dan tidak ada lagi siswa yang mengerjakan pekerjaan rumah.

\section{a. Refleksi}

Pemahaman siswa pada Siklus II tentang pendekatan Kontekstual sudah meningkat. Siswa tidak lagi bingung karena dengan adanya bimbingan ekstra yang dilaksanakan satu persatu terhadap siswa hasilnya sangat memuaskan. Itu ditandai dengan nilai rata-rata tes hasil belajar siswa meningkat. Perubahan-perubahan mendasar ditemukan terhadap siswa pada Siklus II yakni sebagai berikut:

1. Perhatian siswa pada proses pembelajaran dibandingkan Siklus sebelumnya semakin baik. Hal ini ditandai dengan semakin berkurangnya jumlah siswa yang tidak mengikuti proses pembelajaran pada mata pelajaran bahasa Indonesia.

2. Jika pada Siklus I rata-rata persentase jumlah kehadiran siswa selama 3 kali pertemuan (dengan tes akhir siklus) adalah sebanyak 95,39\% maka pada Siklus II dengan 3 kali pertemuan meningkat menjadi $96,05 \%$.

3. Keaktifan siswa untuk mengerjakan tiap tugas yang diberikan juga

4. mengalami peningkatan dibandingkan Siklus I.

5. Kemampuan dan keberanian siswa menanggapi jawaban tugas maupun jawaban soal latihan yang dijawab oleh siswa meningkat. Hal ini ditandai dengan banyaknya siswa yang mengacungkan tangan untuk mengoreksi dan bertanya atau memberikan jawaban yang berbeda dari temannya.

6. Untuk soal-soal yang tingkat kesukarannya hampir sama dengan soal latihan yang telah dibahas sebelumnya, siswa semakin antusias untuk memberikan jawaban walaupun mereka harus melihat dan mengikuti cara kerja dari soal sebelumnya.

\section{b. Keputusan}

Berdasarkan hasil refleksi pada siklus II terlihat bahwa respon siswa sangat positif. Kualitas pembelajaran bahasa Indonesia pada siklus II melalui pendekatan kontekstual untuk materi cerita pendek telah mengalami peningkatan yang signifikan, sehingga penelitian ini diputuskan hanya menggunakan 2 Siklus.

Berdasarkan hasil penelitian, diperoleh bahwa kualitas pembelajaran siswa mengalami peningkatan. Hal ini dapat dilihat dari meningkatnya skor rata-rata dan persentase ketuntasan hasil belajar siswa

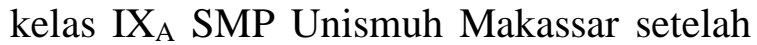
menggunakan pembelajaran dengan pendekatan kontekstual. Peningkatan yang terjadi dapat dilihat pada tabel 7 berikut ini:

Tabel 7 Peningkatan Hasil Belajar Bahasa Indonesia Siswa Kelas IX A $_{\mathrm{A}}$ SMP Unismuh Makassar dari Siklus I ke Siklus II 


\section{Nilai Perolehan dari 34 siswa}

\begin{tabular}{ccccccccc} 
Siklus & Maks & Min & Mean & Median & Modus & St.Dev & Tuntas & T.Tuntas \\
\hline I & 100 & 58 & 75,5 & 74,5 & 76 & 9,87 & 23 & 7 \\
\hline II & 100 & 60 & 82,2 & 80 & 100 & 12,36 & 3 & 27 \\
\hline
\end{tabular}

Disamping terjadinya peningkatan kualitas hasil belajar matematika siswa selama berlangsungnya penelitian dari siklus I sampai siklus II, tercatat sejumlah peningkatan terhadap kualitas proses pembelajaran yang dapat dilihat dari meningkatnya aktivitas siswa berdasarkan hasil observasi siklus I dan siklus II. Peningkatan aktivitas siswa dalam proses pembelajaran dapat dilihat pada tabel 13 berikut:

Pada akhir pertemuan Siklus II terlihat kesungguhan siswa dalam mengikuti proses pembelajaran mengalami kemajuan. Hal tersebut nampak oleh jumlah siswa yang bisa mengerjakan tugas-tugas dengan penuh semangat dan hasilnya cukup memuaskan. Siswa termotivasi untuk menyelesaikan tugas-tugas yang diberikan.

Pada pelaksanaan siklus ini disamping segi pemahaman siswa meningkat dari segi sikap juga mengalami peningkatan baik berupa minat, maupun keinginan untuk mangetahui materi yang disajikan oleh guru. Kesungguhan siswa dalam proses pembelajaran juga mengalami kemajuan. Hal ini terlihat dari jumlah siswa yang hadir mengikuti pelajaran.

Pada Siklus I dan Siklus II, siswa yang melakukan kegiatan lain pada saat pembelajaran dan yang masih perlu dibimbing dalam mengerjakan soal latihan, jumlahnya semakin menurun. Berdasarkan hasil observasi dan refleksi pada Siklus I dengan melihat kelemahan-kelemahan yang ditemukan, maka pada Siklus II diadakan tindakan dengan lebih banyak memberikan motivasi agar siswa lebih semangat dan senang, serta aktif ketika pembelajaran berlangsung.

\section{SIMPULAN}

Kualitas belajaran bahasa Indonesia siswa kelas IX $\mathrm{A}_{\mathrm{A}}$ SMP Unismuh Makassar dengan pendekatan Kontekstual mengalami peningkatan, yang meliputi rata-rata skor hasil belajar bahasa indonesia siswa pada Siklus I adalah 75,5 dalam kategori rendah dengan standar deviasi 9,87. Sedangkan rata-rata skor hasil belajar bahasa Indonesia siswa pada Siklus II sebesar 85,2 dalam kategori tinggi dengan standar deviasi 12,36. Persentase siswa yang mencapai Kriteria Ketuntasan Minimal adalah $76,66 \%$ pada Siklus I, dan $90 \%$ Siklus II.

Aktivitas belajar siswa Kelas IX $_{\mathrm{A}}$ SMP Unismuh Makassar melalui pembelajaran dengan pendekatan Kontekstual meningkat. Hal ini terlihat pada persentase aktivitas siswa pada proses pembelajaran yaitu 98,33\% siswa hadir saat proses pembelajaran berlangsung, $70 \%$ siswa memperhatikan penjelasan guru saat penyajian materi, $14,16 \%$ siswa menjawab pertanyaan lisan guru, $15 \%$ siswa yang mengajukan pertanyaan pada saat penyajian materi, $6,66 \%$ siswa yamg mengajukan diri mengerjakan soal di papan tulis, 5\% siswa membutuhkan bimbingan guru dalam menyelesaikan soal, $48,33 \%$ siswa mengerjakan pekerjaan rumah dan 
7,5\% siswa melakukan kegiatan lain. Keterlaksanaan pembelajaran pada setiap pertemuan sangat baik. Hal ini terlihat pada jumlah persentase setiap pertemuan meningkat. Respon siswa terhadap kegiatan pembelajaran dengan pendekatan Kontekstual direspon dengan positif oleh siswa.

\section{DAFTAR RUJUKAN}

Andira Ayu. 2012. Meningkatkan Hasil Belajar Matematika Melalui Pembelajaran dengan Pendekatan Kontekstual pada Siswa Kelas VIII SMP Negeri 2 Kajang. Skripsi, Jurusan Pendidikan Matematika, Fakultas Keguruan dan Ilmu Pendidikan, Universitas Muhammadiyah Makassar.

Jathee, imperial. 2014. 13 Poin Menulis Cerita Pendek. Yogyakarta: Andi.

Johnson Elaine. 2011. CTL (Contextual Teaching and Learning) Menjadikan Kegiatan Belajar-Mengajar Mengasyikkan dan Bermakna. Bandung: Kaifah Learning.

Kusumaningsih, dewi, dkk. 2013. Terampil Berbahasa Indonesia. Yogyakarta: Andi.

Munirah. 2007. Dasar Keterampilan Menulis. Diktat. Makassar. Fakultas Keguruan dan Ilmu Pendidikan Universitas Muhammadiyah Makassar.

Rahim, Abd. Rahman dan Paelori Thamrin. 2013. seluk beluk bahasa dan sastra indonesiai. Surakarta: Romiz Aisy.

Suryani. 2015. Meningkatkan Kualitas Belajar Matematika Melalui Pendekatan Kontekstual pada Siswa kelas VII C SMP Negeri 1 Bajeng Kab. Gowa. Skripsi. Jurusan Matematika FKIP 